\title{
THE ROLE OF MICROFINANCE IN POVERTY ALLEVIATIONS: CASE STUDY INDONESIA
}

\author{
Mohammad Zeqi Yasin ${ }^{1}$ \\ ${ }^{1}$ Department of Economics, University of Essex \\ Email: my19352@essex.ac.uk
}

\begin{abstract}
The debate on whether microfinance genuinely alleviates poverty has captivated many researchers to investigate this issue. The results are mixed up and varied. Hence, this study aims to convey how the schemes of microfinance can deal with poverty, especially in Indonesia. Moreover, this study also investigates the sustainability of microfinance institutions in dealing with the trade-off between social goal and profit goal. This study employs a descriptive analysis approach with literature study data collection technique. The discussion of this study reveals that the emergence of microfinance in Indonesia, in any ways, has had a significant role as a source of income for poor or micro entrepreneurs. The schemes of conventional and Islamic have also diversified opportunity to gain funding. However, the mix possible success of microfinance, either high-profit goal or high-social goal, have to be seriously concerned. In this regard, the finding implication of this study is that the management structure requires new approaches to avoid such possible mix results. As the involvement of microfinance with most of unexperienced debtors, microfinance institutions as creditor have to, at least, not only provide financial help for the poor, but also offer non-financial help such as training and good relationship. This can be organized along with extending the deeper credit outreach, even if, for absolute poor.
\end{abstract}

Keywords:Microfinance, poverty, Indonesia 


\section{Introduction}

The debate on whether microfinance genuinely alleviates poverty has captivated many researchers to investigate this issue. The results are mixed up and varied. Some studies claimed that microfinance has been considered as a hope that can create financial inclusion for the poor, reduce poverty, and improve household welfare (see: Adnan and Ajija, 2015; Fianto et al., 2018).In relation withYunus (1999)'s argument, poverty eradication can be embarked not by creating jobs for indigents but rather by providing them opportunity to realize their potential, in this case by being micro entrepreneur. Providing poor people microcredit is much better in creating independency of individuals than free transferred grants that possibly create dependency that makes matters worse(Morduch, 1999). Hence, by promoting microfinance, the government enables the poor to take a part in the economic system, minimize dependency, and reduce poverty.

Meanwhile, some studies also argued that microfinance is not a "miracle" as most people believed. For instance, a case of Indonesia, microfinance is served by microfinance institutions (MFIs) such as commercial banks, state-owned pawnshop, secondary banks, cooperatives, and nongovernmental organizations (NGOs)(Takahashi et al., 2010). However, in contrast with pioneer countries of microfinances, e.g. Bangladesh and Bolivia, where the dominating MFIs are NGOs that generally set poverty alleviation as a goal, microfinance activities in Indonesia has been mainly driven by the government through, the most prevalent form, People's Credit Banks (BPRs)(OECD/ERIA, 2018). As a result, banks frequently burden relatively high interest rate to cover operational costs and oblige collateral to prevent the default risk. This circumstance, somehow, creates a trade-off between social and business goals.

However, in the last several years, the issue of default payment, e.g.AndraPadesh's microloans, has been minimized and anticipated by most of the current microloans system. Nonfinancial supports, e.g., business training or human capital development, has been implemented by most of microfinance institutions. Some studies have emphasized theory of social capital and community-building as a distinct strategy to promote reestablishing the economic life of society ( Hadisumarto \& Ghafar, 2010; Evans \& Syrett, 2007; Friedman, 2001; Welsh et al., 2013). In this sense, there are opportunities that microfinance may bring social welfare conditionally.

As there is still a hope that microfinance remains a reliable institution to eradicate poverty, this study aims to discuss how the schemes of microfinance can deal with poverty, especially in Indonesia. The case of Indonesia is unique as this country has two systems of microfinance: conventional and shariah. Hence, this study contributes in literatures by discussing both systems in perspectives of various studies. Moreover, this study also investigates the sustainability of microfinance institutions in dealing with trade-off between social goal and profit goal.The remaining sections are organized as follows. Section 2 discusses literature reviews. Section 3 is research methodology. This section is then followed by section 4 that presents thediscussion. Finally, conclusion and potential further research pieces are explained in the conclusion section. 


\section{Literature Review}

\section{Theoretical Arguments of Poverty Alleviation}

The economists' concern towards poverty issues has generated numerous findings within various perspectives- socio-economic, politic, and geography. For instance,Bolton \& Rosenthal (2005) emphasized the lack accessibility of poor towards formal credit markets caused by many reasons. They argued that among the root causes of this lack of accessibility is because of the credit rationing caused by imperfect information about borrowers' creditworthiness. Along with that assumption, lenders might anticipate that imperfect information by offering higher interest rate which most of the case would be only taken by riskier and more desperate borrowers. Conversely, the lower interest can only be offered for the highest bidder which is supposedly not classified as a poor.

Associated with that issue, credit rationing also stems from discrimination and out of lenders' exaggerated concerns about minority borrowers' creditworthiness(Blanchflower, Levine, and Zimmerman 2003). Most of the lenders, with their authority, might be less likely to prioritize the poor even if they have sufficient requirement and are as creditworthy as other borrowers. Another cause is that poor people are less able to provide collateral to reduce the risk of default. These create vicious cycle of poverty- poor people cannot provide collateral because they are poor and lenders cannot offer credit, that may will escape poor people from poverty, without collateral. Hence, for most of the case, poor people will be excluded from the formal credit market.

Likewise, in a more specific case such as micro entrepreneurs that in many evidences empower poor people and propose credit for their micro business, the lack of access towards credit market such as bank or other financial institutions is also caused by imperfect information.Adam \& Lestari (2017) distinguished this cause into the two sidesdemand and supply. The demand side is related to the microentrepreneurs believing that the banks' lending rate is too expensive, or because they believe that they will not be qualified for the requirements such as collateral, audited book accounts, cash flow projections, and business plans. In the supply side, bank is risk-averse to disburse loans to microentrepreneurs due to high risk default. Imperfect information causes credit rationing and again creates the vicious cycle- if bank could determine which microbusinesses are more likely to benefit and grant them loans over those who are more likely to default, then banks do not have to be risk averse, but most of microentrepreneurs are not experienced debtors and have no business plans or book accounts in which bank will use to assess creditworthy business(Nugroho 2009). As such, there are two issues of lack accessibility background toward credit markets- poor people and microentrepreneurs. Similarly,Banerjee et al. (2015) classified these issues into two categories- those who use loans for consumption and those who use loans for business expansion (or opening) which related to the microbusiness.

Knowing that the poor people (or microentrepreneurs) are difficult to access credit markets, more-flexible credit option is mandatory. Many people have recognized the presence of Grameen Bank specializing on small and short-term credit, so as called microcredit to relatively poor individuals or groups. Microcredit, in most cases, has unique aspects that does not exist in formal financial institutions. Characteristic of microcredit is to 
provide small loans to the poor, using various innovative nonconventional loan elements such as loans without collateral or collateral substitutes, progressive loan structure, group lending, progressive loan structure, weekly repayment, and forced savings(Quayes 2012; Morduch 1999). Instance for group lending was pioneered by Grameen Bank that enabled borrowers to obtain loans by forming group that monitor each other's repayment responsibility. This system is somehow ideal to accommodate poor people, notably woman, who are most likely to start out as inexperienced debtor. If the first loan is successfully repaid, the group can gain higher ceiling credit and propose more loans than the first one.

\section{Poverty Alleviation in Indonesia}

Indonesia's effort to alleviate poverty is an international success story (Perdana 2014). According to the Central Bureau of Statistic of Indonesia, there are approximately 9.22 percent of the total population living under the poverty line in September 2019 (Figure 1), compared to 14.15 percent of the population in March 2009. It means that more than 12 million people have successfully escaped from poverty in just a decade.

Figure 1. Number and Percentage of Poor People of Indonesia in March 2009-September 2019

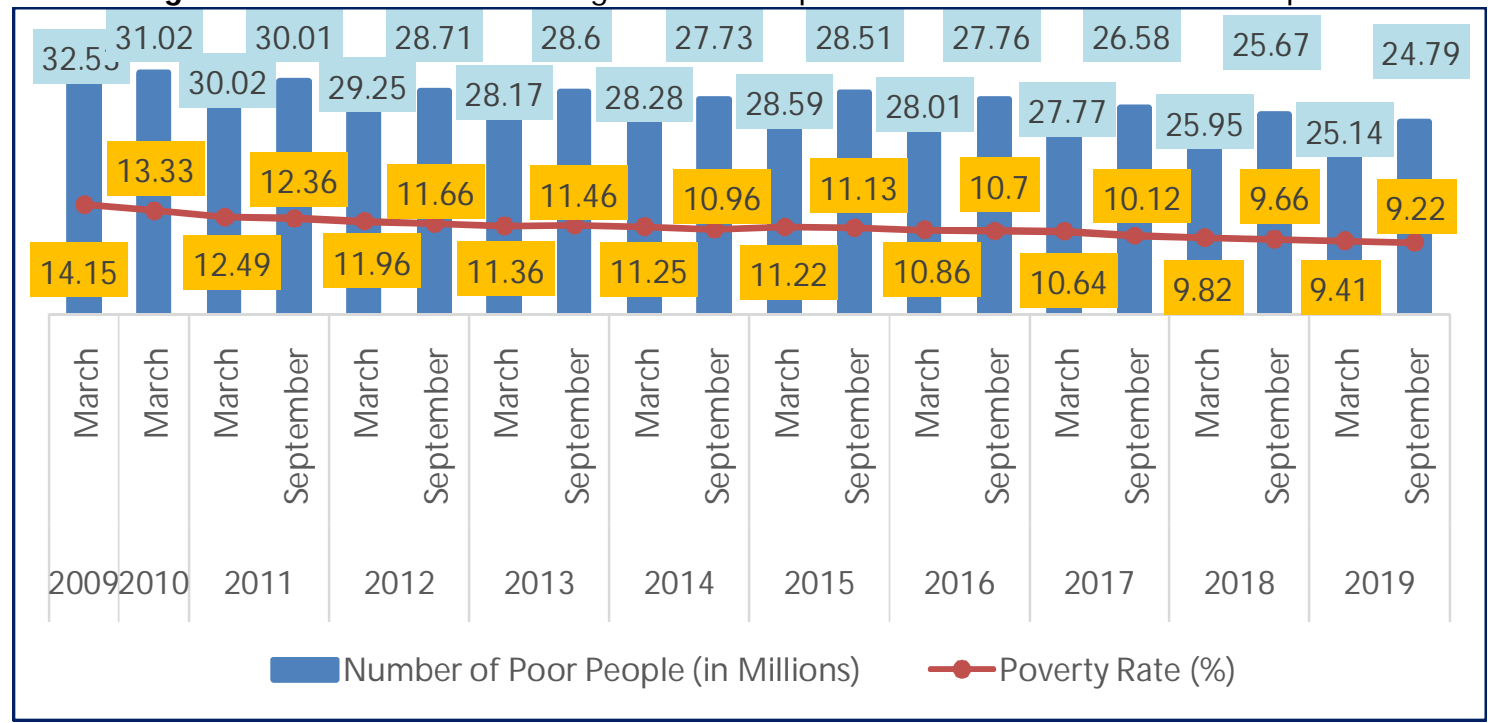

Source: Central Bureau of Statistic of Indonesia (2019)

In its 2009-2014 medium-term development agenda, the Indonesian Government set a target to reduce poverty rate to 8-10 percent(Perdana 2014). This target was pursued through the clustering program of the poor into three clusters. Cluster 1 consists some social assistance programs e.g. subsidized rice (Raskin or rice for the poor) a conditional cash transfer program e.g. Program Keluarga Harapan (PKH or The Family of Hope program), and BantuanSiswa Miskin (BSM or educational assistance for poor students), Cluster 2 targets communities to be developed under the Program Nasional Pemberdayaan Masyarakat (PNPM or national community empowerment program), and the microfinance is accommodated by Cluster 3 that is micro, small- and medium enterprises (MSMEs) as a target through the partial government-guarantee scheme for bank credit called Kredit Usaha Rakyat (KUR or Micro Credit Program). 
Cluster 3 as a goal to alleviate poverty associates with the microfinance schemes. The specific schemes of microfinance in Indonesia were created to accommodate a diversity of preferences: interest rate scheme of conventional microfinance or profit-loss sharing scheme (PLS) of Islamic microfinance. Interest rate scheme has been employed by most of microcredit provider classification in Indonesia such as NGO-based, commercial-based, government-based, and informal, while PLS currently has been widely adopted by Islamic microfinances e.g.Baitul Mal Wattamwil (BMT). The notable distinction of shari'ahsystem (system with Islamic law) with the conventional system that employs interest rate is the sharing system; either a business faces loss or profit.

\section{Research Methods}

The research approach in this study is qualitative. This approach attempts to understand phenomena experienced by research subjects such as perception, behaviour, motivation, and action(Moleong 2007). In this regard, qualitative approach is a method that employs elaborated words that are descriptive, use analysis, refer to data, utilize existing theories as supporting material, and establish a theory(Farhand, Nurjanah, and Nurcholis 2020).

The literature study is the technique of data collection used in this study.Nazir (2014)contented that data collection technique is conducted through reviewing the books, literature, records, and reports that relate to the issues being solved. This study is basically a case study of microfinance in Indonesia. In this regard, this study conveys most of findings compared to the Indonesian context. Nevertheless, this study also attempts to elaborate the analysis by exploring some findings related to the issues of Indonesian microfinance. In this sense, this study can compare the empirical condition in Indonesian and the global scale regarding microfinance.

\section{Result and Discussions}

\section{Findings of Indonesian Microfinance in Reducing Poverty}

Tabel 1 Indonesian Microfinance in Reducing Poverty

\begin{tabular}{|l|l|l|l|}
\hline Year & Author & Title & Findings \\
\hline 2009 & Nugroho & $\begin{array}{l}\text { The Pro-poor Policy } \\
\text { of Microfinance in } \\
\text { Indonesia }\end{array}$ & $\begin{array}{l}\text { The commercialization } \\
\text { approach proposes that } \\
\text { profitability and the outreach } \\
\text { capacity of MFIs to serve the } \\
\text { poor do not counteract each } \\
\text { other. } \\
\text { Instead, profitability can be a } \\
\text { milestone of MFIs to serve poor } \\
\text { under the sustainable operation. }\end{array}$ \\
\hline 2010 & $\begin{array}{l}\text { Takahashi et } \\
\text { al. }\end{array}$ & $\begin{array}{l}\text { The Short-Term } \\
\text { Poverty Impact of } \\
\text { Small-Scale, }\end{array}$ & $\begin{array}{l}\text { The access to microcredit was } \\
\text { dominated by the richer } \\
\text { families even though collateral }\end{array}$ \\
\hline
\end{tabular}




\begin{tabular}{|c|c|c|c|}
\hline & & $\begin{array}{l}\text { Collateral-Free } \\
\text { Microcredit in } \\
\text { Indonesia: } \\
\text { A Matching } \\
\text { Estimator Approach }\end{array}$ & $\begin{array}{l}\text { ownership is not a required } \\
\text { determinant of credit } \\
\text { participation } \\
\text { The impact of microcredit on } \\
\text { vast household outcomes is } \\
\text { statistically insignificant, except } \\
\text { for sales of nonfarm enterprises } \\
\text { for the nonpoor and schooling } \\
\text { expenditures for the poor. } \\
\text { - This implies that the } \\
\text { microcredit scheme under } \\
\text { study might not have an } \\
\text { immediate impact on poverty } \\
\text { eradication. }\end{array}$ \\
\hline 2010 & $\begin{array}{l}\text { Bin Mislan } \\
\text { Cokro } \\
\text { Hadisumarto } \\
\text { \& Ghafar }\end{array}$ & $\begin{array}{l}\text { Improving the } \\
\text { effectiveness of } \\
\text { Islamic micro- } \\
\text { financing } \\
\text { Learning from BMT } \\
\text { experience }\end{array}$ & $\begin{array}{l}\text { The implementation of Islamic } \\
\text { micro-financing incorporated } \\
\text { with business control, incentive } \\
\text { system, and construct good } \\
\text { relationship is effective in } \\
\text { developing micro-enterprises } \\
\text { and improving the household } \\
\text { income. } \\
\text { - An integrated program as an } \\
\text { effort to improve the } \\
\text { effectiveness of Islamic micro- } \\
\text { financing remains essential. }\end{array}$ \\
\hline 2013 & $\begin{array}{l}\text { Hasanah \& } \\
\text { Yusuf }\end{array}$ & $\begin{array}{l}\text { Determinants of the } \\
\text { Establishment } \\
\text { of Islamic Micro } \\
\text { Finance } \\
\text { Institutions: } \\
\text { The Case of Baitul } \\
\text { MaalwaTamwil } \\
\text { (BMT) in Indonesia }\end{array}$ & $\begin{array}{l}\text { - The area at which agriculture } \\
\text { sector and high accessibility to } \\
\text { market are strong affects the } \\
\text { BMT establishment in } \\
\text { Indonesian villages. } \\
\text { - Villages that experienced } \\
\text { recent calamities particularly } \\
\text { drought are more likely to own } \\
\text { BMT established. } \\
\text { Villages where Islam as the } \\
\text { dominant religion is more } \\
\text { likely to have BMT } \\
\text { established.However, this } \\
\text { effect is strong only in rural } \\
\text { areas. In urban areas, this effect } \\
\text { is weak. }\end{array}$ \\
\hline 2015 & $\begin{array}{l}\text { Adnan } \quad \& \\
\text { Ajija }\end{array}$ & $\begin{array}{l}\text { The effectiveness of } \\
\text { Baitul Maal } \\
\text { wat Tamwil (BMT) in } \\
\text { reducing poverty }\end{array}$ & $\begin{array}{l}\text { BMT financing is effective in } \\
\text { alleviating poverty through the } \\
\text { increase of income. } \\
\text { - BBA and mudarabah, to }\end{array}$ \\
\hline
\end{tabular}




\begin{tabular}{|c|c|c|c|}
\hline & & & $\begin{array}{l}\text { empower the poor in various } \\
\text { productive businesses,can } \\
\text { reduce the extent and severity } \\
\text { of poverty. }\end{array}$ \\
\hline 2017 & $\begin{array}{l}\text { Adam } \quad \& \\
\text { Lestari }\end{array}$ & $\begin{array}{l}\text { Indonesia's } \\
\text { Guaranteed } \\
\text { Microfinance } \\
\text { Programme (KUR) }\end{array}$ & $\begin{array}{l}\text { KUR 's role in accelerating } \\
\text { poverty alleviation remains } \\
\text { questionable as there are many } \\
\text { poor households could not } \\
\text { access the programme. } \\
\text { - The main policy challenges are } \\
\text { the improvement of KUR } \\
\text { design to minimize asymmetric } \\
\text { information, ensuring that } \\
\text { KUR meets its anti-poverty } \\
\text { goals by reaching the suitable } \\
\text { sectors and regions, and the } \\
\text { strengthening the KUR Policy } \\
\text { Committee 's oversight and } \\
\text { ability to coordinate across } \\
\text { stakeholders }\end{array}$ \\
\hline 2018 & Fianto et al. & $\begin{array}{l}\text { Equity financing and } \\
\text { debt-based } \\
\text { financing: Evidence } \\
\text { from Islamic } \\
\text { microfinance } \\
\text { institutions in } \\
\text { Indonesia }\end{array}$ & $\begin{array}{l}\text { - Both financing groups revealed } \\
\text { a positive and significant } \\
\text { impact on rural households' } \\
\text { income, but equity financing } \\
\text { showed better than debt-based } \\
\text { financing. } \\
\text { - The finding indicates that most } \\
\text { clients of Islamic MFIs are not } \\
\text { very poor as most clients } \\
\text { required collateral before } \\
\text { receiving financing. In this } \\
\text { sense, the Islamic MFIs do not } \\
\text { really target the poorest people } \\
\text { in Indonesia. }\end{array}$ \\
\hline
\end{tabular}

Several studies have investigated the effectiveness of microfinance to improve welfare of Indonesian microentrepreneurs(Takahashi, Higashikata, and Tsukada 2010; Nugroho 2009; Adam and Lestari 2017). Study ofTakahashi et al. (2010) combined Propensity Score Matching (PSM) approach and Different-in-Different (DID) approach to examine the prosperity of the emerging microcredit scheme of bank-mixed-NGO (Bank Rakyat Indonesia\&Yayasan Bina Swadaya, so called BRI-YBS) in targeting and promoting the poor's welfare. They held survey for 100 participants of a BRI-YBS selected by the BRI-YBS and 100 non-participants selected by the authors that both of it are treated group in the treated villages. Meanwhile, 250 households were selected as control group. The survey was held twice-in the 2007 when loans had not been disbursed and in the 2008 when loans had been 
distributed. They conclude that despite the collateral-free scheme might actually work in captivating debtors, but most of the participants were relatively wealthier family that had higher per capita income and more access to microcredit. Subsequently, the impact of microcredit was not statistically significant on most outcomes such as household income and self-employed business' profit, yet, in contrast, microcredit significantly enlarged the business size had by treatment households more than that had by control households. Specifically, that business size, proxied by the volume of sales, were greater for business owned by the poor than that owned by the nonpoor.

In terms of the application of profit-loss sharing system in Indonesia, Baitul Maal Wat Tamwil(BMT) is one of the Islamic microfinance institutions (MFIs) that adopted Profit-Loss Sharing (PLS) scheme. The term Baitul Mal Wat Tamwil means that BMT has dual missions: Baitul Tamwil as business mission and Baitul Maal as social mission (Hadisumarto and Ismail, 2010). Business mission is applied through various financial services. BMT practically offers various products that resemble Islamic Banks' products. However, a notable difference between these two institutions is the dedicated clients: middle- and upper-income group for Islamic bank and low-income micro-entrepreneurs for BMT(Adnan and Ajija 2015). BMT offers two essential products of financing: Mudarabah(profit-sharing) andMusharakah(joint venture). Mudarabahis a profit-sharing agreement where an Islamic Microfinance Institution provides all the capital required in the project or business, while the clients devote their time and effort to the project. The profits will be shared in a fixed ratio between microfinance institution (MFI) and the clients, and losses will be borne by MFI. Meanwhile, Musyarakahis a PLS agreement contract which two or more parties contribute their equity and both profits and losses will be shared and borne on an equity participation basis(Fianto et al. 2018). Meanwhile, social mission is through the obligation of ZakahandSadaqahas charity instruments that expectedly contribute to poverty alleviation. This obligation remarkably distinguishes the Islamic MFIs and the conventional ones.

A number of studies look at Islamic microfinance practices in Indonesia (Adnan \& Ajija, 2015; Bin Mislan Cokro Hadisumarto \& Ghafar, 2010; Fianto et al., 2018) and other countries(Rahman 2013; Onakoya and Onakoya 2013). Study of Adnan \& Ajija (2015)discovered that Islamic microfinance (BMT) significantly reduced poverty through the increasing income of its members. Internalizing Islamic value that was designed by the BMT through the integrated programs for poor such as the provision of financial and nonfinancial services including spiritual development evidently, becomes the essential tools to expand the income source of poor.

The effectiveness of microfinance in alleviating poverty is also emphasized through the spatial approach that examined the pivotal causes of the income-related impact disparity yielded its implications for the micro financing in alleviating poverty(Shaw 2004; Hasanah and Yusuf 2013). By examining country of Srilanka,Shaw (2004) discovered that there are different poverty impacts distinguished by location, for example the greater opportunities had by poor clients (by being microentrepreneurs) in semi-urban locations to combat poverty than those who are poor in rural areas. This unequal opportunity stems from the severe market as well as infrastructure constraints in the rural areas. This finding implies 
that the development of microenterprises operated by microentrepreneurs, notably in the rural, requires complemented supports of investment in physical and social infrastructure. Hence, the development spending through micro loans for projects of rural areas will effectively eradicate poverty.

For the specific case of Islamic microfinance of Indonesia using spatial analysis, Hasanah \& Yusuf (2013)examined the determinants of the BMT establishment in Indonesia. By employing 310 households micro-level data of Indonesia Family Life Survey (IFLS), this study found several significant factors of BMTs' establishment in Indonesia i.e. the presence of agriculture sector in the village, the distance of the village to the market, the dominating religion adhered by villagers, drought of a village, and location of the village. This study discovered that location of the village, either in urban or rural area, has the largest positive marginal effect among other dummy variables tested by $24.5 \%$. It means that the likelihood of BMT being located in urban areas of a village is $24.5 \%$ greater than being located in rural areas. The positive sign is also showed by the determinant of dominantly Muslim village. It means that the village with dominantly Muslim increase the probability of BMT established. However, they also noted that the interaction variable of dominating religion and location evidently showed strongly significant in negative direction. This finding argues that the positive influence of religion is weakened by BMT being placed in urban areas. If a village is dominantly Muslim and located in urban areas, it will attenuate the probability of the BMT built. Therefore, it can be concluded that even if BMT is an Islamic microfinance institution that its essence is prioritizing Muslim users, yet, spatial factor evidently has stronger effect than that essence itself.

\section{The Way in Which Microfinance Deals with Sustainability Issues}

The previous section has elaborated how the microfinance, both conventional and Islamic microfinances, contribute to poverty alleviation specially Indonesia's case. However, it is also worth noting that since microfinance is largely involved with middlelower income people, microfinance frequently faced mix trade-off in maintaining sustainability. As Nugroho (2009)argued about the trade-off between the profitability and the outreach goals of Indonesia's microbanks to serve poor people, indeed, microfinance institutions are recognized as an alternative source of funding for poor, but their business operations will be somewhat similar with other for-profit commercial financial institutions that accords prudent standard of banking. As postulated byMorduch (2000), there is a strong consensus that the most vigorous effect of poverty will mainly occur for microfinance system focusing on profitability through high interest rate. Although, then, this consensus is at odds with real practice where some of microfinance remains non-profit oriented, relying on subsidies, unsustain. Hence, the diverse array of fundamental purposes, such as socially oriented and profit-oriented, that are to improve poor's welfare should be consistently maintained.

Another instance of that trade-off was discovered byHermes et al. (2011) which stated that the outreach of microfinances negatively correlated with the efficiency. It means that improving efficiency can be achieved if only microfinances focus less on poor clients. This notion then generated two-sides perspectives. In one side, it could not be ignored that the 
goal of microfinance is to foster the welfare of poor through empowering microentrepreneurs and enhancing the outreach of the poor in accessing microfinance, but in the other side, somehow, that outreach must create trade-off and considerable costs that can be covered primarily by the high interest-rate (or high margin proportion for Islamic microfinance).

Several arguments were obliquely aligned into two strongholds: pro-poor and proprofit-for-microfinance.Quayes (2012) argued that the large number of microfinance programs operating nowadays dominantly rely on the patron agencies to grant them the steady flow of funding, so that the credit outreach of the poor can actually be deeply achieved. Instance of this is Indonesia's KUR that was initiated by government. As government targeted low poverty by, one of which, executing Cluster 3, it means that they should hold microfinance by injecting capital as much as possible even though this approach, somehow, is not properly suitable for long-term independency of microfinances. In contrast,Morduch (1999) argued that sustainable microfinance programs supposedly have to not reach poor people in large proportion. Coupled to this statement,Cull et al. (2007) suggested that the sustainability of profit can be maintain as long as microfinance does not enhance credit outreach to the very absolute poor. These notions are somewhat cliché as the target of microfinance is originally for poor. Regardless of which one that is more ideally appropriate, these two arguments similarly were stated to solely support poor and sustain microfinances.

Another perspective of sustainability goal that might be considered by microfinance is the competitiveness among the institutions. A large growth of microfinances that are in operation today have inevitably generated competitive environment. In theory, competitive environment may increase the performance of microfinance to gain profit as they have more pressure to be financially sustained by carefully operating in the most efficient level, but again, this may create trade-off between social purpose and the financial performance. However, increasing performance of financial institutions is ambiguous. In one side, an institution might attempt to be innovative by developing new products and efficient technologies(Assefa, Hermes, and Meesters 2013) but, in the other side, oppositely,McIntosh \& Wydick (2005) stated that adverse effect might occur among financial institutions competition when they competitively lowered the borrowing standard to captivate debtors, so that high default might happen.

Aforementioned issues of trade-off between social goals and financial performance of microfinance can ideally be solved, or at least minimized, by additional efforts given by microfinance institutions (MFIs). Instances of performance vs. outreach, such as Hermes et al. (2011), are also necessarily able to be avoided when MFIs can maintain communication with the poor borrowers and effectively monitor their business activities. These strategies will help bring positive dynamics in lending so that the poor can compensate the risk and cost that emerged when MFIs provide those loans.

In practical example of Indonesia, study of Hadisumarto \& Ghafar (2010) demonstrated how additional efforts on microfinance program might contribute generating positive dynamics for poor and MFI. By employing the case of BMT, they mentioned several mandatory and additional processes to avoid fraud and moral hazard: selection process 
and business control as commonly mandatory processes and additionally (that might not all MFI commit to) with incentive and good relationship. Selection process is related to the legal capacity standard of the borrower. This process includes administrative selection, interview, and feasibility study of the business. Subsequently, business control constitutes attempt to reduce deviation of the fund of micro-entrepreneurs for other purposes outside the business matters. Offering incentives (such as scholarship for children, enhance financing ceiling, or profit payment discount) is also an attempt to minimize the Nonperforming Financing (NPF) as an indicator to sustain Islamic MFIs. Furthermore, constructing good relationship with micro-entrepreneurs (such as visitation on wedding parties, personal approach, or religious advice) is also essential in establishing the community atmosphere between BMTs and microentrepreneurs.

By applying aforementioned requirements along with the Islamic financing scheme applied by BMTs,Hadisumarto \& Ghafar (2010) discovered that there is significant improvement of microentrepreneurs' income after joining BMT. They noted that the participation rate of micro-entrepreneurs to propose financing in BMT also climbed up at $76 \%$ from 2002 to 2005. An increase of the business' revenue was followed by an increase in household income. This significant raise was accompanied by an increase in savings as well as an improved ability to satisfy basic needs. Thus, possible trade-off of microfinances can be anticipated so that both social and profit goal can be parallel attained.

\section{Conclusion}

This study investigates how the schemes of microfinance deal with poverty, especially in Indonesia. Moreover, this study also investigates the sustainability of microfinance institutions in dealing with trade-off between social goal and profit goal. The presence of microfinance in Indonesia, in any ways, has had significant role as source of income for poor or microentrepreneurs. The schemes of conventional and Islamic have also diversified opportunity to gain funding. However, the mix possible success of microfinance, either high-profit goal or high-social goal, have to be seriously concerned.

This finding implies into policy implication for Indonesian microfinance that the management structure requires new approaches to avoid such possible mix results. As the involvement of microfinance with most of unexperienced debtors, microfinance institutions as creditor have to, at least, not only provide financial help for the poor, but also offer nonfinancial help such as training and good relationship. This can be organized along with extending the deeper credit outreach, even if, for absolute poor.

However, this study has a limitation wherein the author does not employ quantitative analysis to enrich the analysis. In this regard, further studies are necessary to elaborate and statistically prove the arguments in this study. Hence, the analysis can be more reliable and robust.

\section{References}

[1]Adam, Latif, and Esta Lestari. 2017. "Indonesia's Guaranteed Microfinance Programme (KUR): Lessons from the First Stage of Implementation." Journal of Southeast Asian 
Economies 34 (2): 322-44. https://doi.org/10.1355/ae34-2e.

[2]Adnan, Muhammad Akhyar, and Shochrul Rohmatul Ajija. 2015. “The Effectiveness of Baitul Maal Wat Tamwil in Reducing Poverty the Case of Indonesian Islamic Microfinance Institution." Humanomics 31 (2): 160-82. https://doi.org/10.1108/H-032012-0003.

[3]Assefa, Esubalew, Niels Hermes, and Aljar Meesters. 2013. "Competition and the Performance of Microfinance Institutions." Applied Financial Economics 23 (9): 767-82. https://doi.org/10.1080 09603107.2012.754541.

[4]Banerjee, Abhijit, Esther Duflo, Rachel Glennerster, and Cynthia Kinnan. 2015. "The Miracle of Microfinance? Evidence from a Randomized Evaluation." American Economic Journal: Applied Economics 7 (1): 22-53. https://doi.org/10.1257/app.20130533.

[5]Blanchflower, D G, P B Levine, and D J Zimmerman. 2003. "Discrimination in The SmallBusiness Credit Market." Review of Economics and Statistics 85 (4): 930-43.

[6]Bolton, Patrick, and Howard Rosenthal. 2005. "Introduction." In Credit Markets for The Poor, 1-14. Russell Sage Foundation.

[7]Cull, R, A Demirgu C-Kunt, and Jonathan Morduch. 2007. "Financial Performance and Outreach: A Global Analysis of Leading Microbanks." The Economic Journal 117 (517): F107-33.

[8]Evans, Mel, and Stephen Syrett. 2007. "Generating Social Capital?" European Urban and Regional Studies 14 (1): 55-74. https://doi.org/10.1177 0969776407072664.

[9]Farhand, Muhammad Zaid, Putri Leli Nurjanah, and Muhammad Nurcholis. 2020. "Islamic Finance In Sustainable Economy®: Empowerment Of Sukuk Wakalah To Build Waste Industry." Airlangga International Journal of Islamic Economics and Finance 3 (1): 52-67.

[10]Fianto, Bayu Arie, Christopher Gan, Baiding Hu, and Jamal Roudaki. 2018. “Equity Financing and Debt-Based Financing: Evidence from Islamic Microfinance Institutions in Indonesia." Pacific Basin Finance Journal 52 (August 2016): 163-72. https://doi.org/10.1016/j.pacfin.2017.09.010.

[11]Friedman, Jason J. 2001. "The Role of Microenterprise Development in Stimulating Social Capital and Rebuilding Inner City Economies:" The Journal of Socio-Economics 30 (2): 139-43. https://doi.org/10.1016/s1053-5357(00)00094-9.

[12]Hasanah, Alfiah, and Arief Anshory Yusuf. 2013. "Working Paper in Economics and Development Studies Determinants of the Establishment of Islamic Micro Finance Institutionso: The Case of Baitul Maal Wa Tamwil ( BMT ) in Indonesia Alfiah Hasanah Arief Anshory Yusuf ( Center for Economics and Development D," no. 6.

[13]Hermes, Niels, Robert Lensink, and Aljar Meesters. 2011. "Outreach and Efficiency of Microfinance Institutions." World Development 39 (6): 938-48.

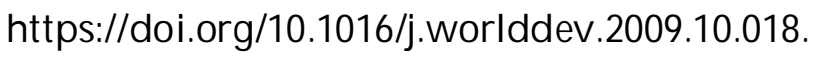

[14]McIntosh, Craig, and Bruce Wydick. 2005. "Competition and Microfinance." Journal of Development Economics 78 (2): 271-98. https://doi.org/10.1016/j.jdeveco.2004.11.008.

[15]Mislan Cokro Hadisumarto, Widiyanto Bin, and Abdul Ghafar. 2010. "Improving the Effectiveness of Islamic Micro-Financing: Learning from BMT Experience." Humanomics 26 (1): 65-75. https://doi.org/10.1108 08288661011025002. 
[16]Moleong, Lexy J. 2007. Metode Penelitian Kualitatif Edisi Revisi. Bandung: PT. Remaja Rosdakarya 103.

[17]Morduch, Jonathan. 1999. "The Role of Subsidies in Microfinance: Evidence from the Grameen Bank." Journal of Development Economics 60 (1): 229-48. https://doi.org/10.1016 \$0304-3878(99)00042-5.

[18]_ 2000. “The Microfinance Schism." World Development 28 (4): 617-29.

[19]Nazir, Moh. 2014. Metode Penelitian Cetakan 9. Bogor: Ghalia Indonesia.

[21]Nugroho, Agus Eko. 2009. "The Pro-Poor Policy of Microfinance in Indonesia." Gadjah Mada International Journal of Business 11 (3): 317. https://doi.org/10.22146/gamaijb.5523.

[22]OECD/ERIA. 2018. SME Policy Index: ASEAN 2018: Boosting Competitiveness and Inclusive Growth. Paris Jakarta: OECD Publishing/Economic Research Institute for ASEAN and East Asia.

[23]Onakoya, Adegbemi Babatunde, and Adefisayo Olasunkanmi Onakoya. 2013. "Islamic Microfinance as a Poverty Alleviation Tool: Expectations from Ogun State, Nigeria." Scholarly Journal of Business Administration 3 (2): 36-43.

[24]Perdana, Ari A. 2014. "The Future of Social Welfare Programs in Indonesia: From Fossil-Fuel Subsidies to Better Social Protection."

[25]Quayes, Shakil. 2012. "Depth of Outreach and Financial Sustainability of Microfinance Institutions." Applied Economics $44 \quad$ (26): 3421-33. https://doi.org/10.1080 00036846.2011.577016.

[26]Rahman, Md. Mizanur. 2013. "Islamic Microfinance: A Tool for Poverty Alleviation." Asia-Pacific Journal of Rural Development 23 (1): 119-20. https://doi.org/10.1177/1018529120130109.

[27]Shaw, Judith. 2004. "Microenterprise Occupation and Poverty Reduction in Microfinance Programs: Evidence from Sri Lanka." World Development 32 (7): 1247-64. https://doi.org/10.1016 §.worlddev.2004.01.009.

[28]Takahashi, Kazushi, Takayuki Higashikata, and Kazunari Tsukada. 2010. “The ShortTerm Poverty Impact of Small-Scale, Collateral-Free Microcredit in Indonesia: A Matching Estimator Approach." Developing Economies 48 (1): 128-55. https://doi.org/10.1111 ð.1746-1049.2010.00101.x.

[29]Welsh, Dianne H.B., J. Mark Munoz, Shengliang Deng, and Peter V. Raven. 2013. "Microenterprise Performance and Microenterprise Zones (MEZOs) in China." Management Decision 51 (1): 25-40. https://doi.org/10.1108 00251741311291292.

[30]Yunus, Muhammad. 1999. “The Grameen Bank.” Scientific American 281 (5): 114-19. 